\title{
BIOACCUMULATION OF LEAD, CADMIUM AND MERCURY IN Argopecten purpuratus (LAMARCK, 1819) AND Aulacomya ater (MOLINA, 1782), COMMERCIAL SPECIES FROM PERU, AND RISK ASSESSMENT
}

\author{
BIOACUMULACIÓN DE PLOMO, CADMIO Y MERCURIO EN \\ Argopecten purpuratus (LAMARCK, 1819) Y Aulacomya ater (MOLINA, 1782), \\ ESPECIES COMERCIALES DEL PERÚ, Y SU EVALUACIÓN DE RIESGO A LA \\ SALUD
}

\author{
Maritza Barriga-Sánchez ${ }^{1}$ and Diana Aranda Pariasca
}

\begin{abstract}
The aim of the study was to determinate the level of lead, cadmium and mercury on the edible part of Peruvian scallop (Argopecten purpuratus Lamarck, 1819) and mussel (Aulacomya ater Molina, 1782) from 2009 to 2012 in the major production areas of Peru and to compare the results with the maximum levels set by the European Union (EU) and consequently evaluate any health risks for consumers. Peruvian scallop samples from suspended culture were extracted from growing areas of Sechura, Samanco and Paracas. Mussel samples were extracted from natural banks from Marcona and Atico. THQ (target hazard quontient) values for $\mathrm{Pb}, \mathrm{Cd}, \mathrm{Hg}$ in Peruvian scallops, plus $\mathrm{Pb}$ and $\mathrm{Hg}$ in mussels were less than 1 (even less than 0.25 ), unlike $\mathrm{Cd}$ in mussels from Marcona and Atico which exceeded the maximum level allowed and presented THQ values greater than 1, representing a possible health risk. A maximum weekly consumption rate was estimated.
\end{abstract}

Key words: heavy metals, bivalve, Argopecten purpuratus, Aulacomya ater, bioaccumulation.

\section{Resumen}

El objetivo del estudio fue determinar los niveles de plomo, cadmio y mercurio en la parte comestible de la concha de abanico (Argopecten purpuratus Lamarck, 1819) y el choro (Aulacomya ater Molina, 1782) en el periodo 2009 al 2012 en las principales áreas de producción del Perú y comparar los resultados con los niveles máximos establecidos por la Union Europea y en consecuencia, evaluar los riesgos para la salud de los consumidores. Las muestras de concha de abanico fueron extraídas de cultivos suspendidos ubicados en Sechura, Samanco y Paracas. Las muestras de choro fueron extraídas de bancos naturales ubicados en Marcona y Atico. Los valores de THQ (cociente de riesgo) para $\mathrm{Pb}, \mathrm{Cd}, \mathrm{Hg}$ en concha de abanico, asi como el $\mathrm{Pb}$ y $\mathrm{Hg}$ en choro fueron menores que 1 (incluso menos de 0.25 ), a diferencia del $\mathrm{Cd}$ en choro de Marcona y Atico que excedieron el nivel máximo permitido y presentaron valores de THQ mayores a 1, lo que representa un posible riesgo para la salud. Una tasa máxima de consumo semanal fue estimada para estos recursos.

Palabras clave: metales pesados, bivalvos, Argopecten purpuratus, Aulacomya ater, bioacumulacion.

\section{Introduction.}

Scallops and mussels are the two bivalve molluscs with the highest rate of extraction and consumption in Peru. In 2015, 30396 tons of scallops and 5866 tons of mussels were harvested (PE, 2016). The mussel, Aulacomya ater (Molina, 1782) is highly popular mollusc of which there is a continuous and uncontrolled extraction causing exhaustion of some natural banks (Gamarra \& Cornejo, 2002). It is distributed geographically in the Pacific from Chimbote (Peru) to the Strait of Magellan and island Juan Fernández (Chile), in the Atlantic until the south of Brazil and Malvinas island (Alamo \& Valdivieso, 1997).
Peruvian scallop, Argopecten purpuratus (Lamarck 1819), is the most important bivalve in Peru due its great demand on both the national and international market. It is distributed from Paita (Peru) to Coquimbo (Chile) (Alamo \& Valdivieso, 1997). It is the species which presents the largest aquaculture production in Peru, developed through a suspended cultivation system. In 2015, the greatest scallops's production areas were: Casma (Ancash) with 10833.93 tons, Paracas (Ica) with 303.06 tons and Sechura (Piura) with 11891.59 tons (PE, 2016). 


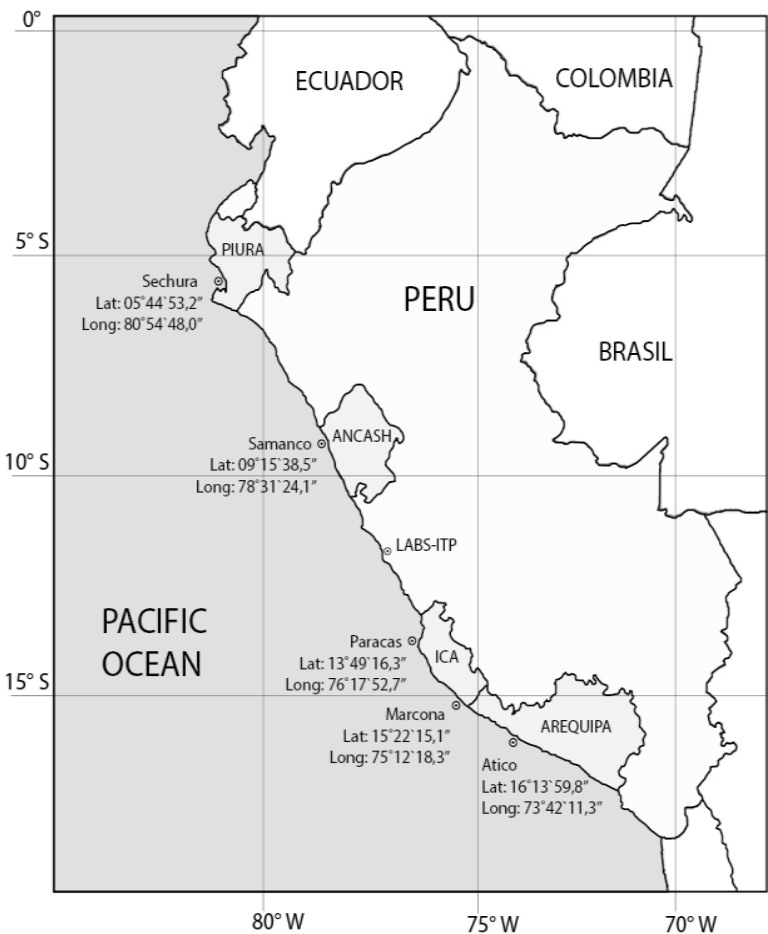

Figure. 1. Map with the geographical location of sampling areas.

The greatest natural banks of mussel are Marcona and Atico (IMARPE, 2013). Actually, Peru doesn't have an aquaculture system for this resource.

In December 2008, field work was carried out in Samanco, they found that the aquatic quality of the marine environment didn't have a major impact. The average concentration of total suspended solids, indicators of organic and microbial contamination, heavy metals such as $\mathrm{Cd}, \mathrm{Pb}$ and $\mathrm{Cu}$ in water and marine resources, didn't exceed the values stipulated by the Coastal Protection and Restoration Table (USA), but on superficial sediments some heavy metals such as $\mathrm{Cd}$ and $\mathrm{Cu}$ exceeded these values. The use of fuels on mariculture activities, artisanal and industrial fisheries contributed to the accumulation of $\mathrm{Cd}$ in Samanco sediments (IMARPE, 2009).

During August to December 2015, in Sechura the largest area of scallop`s cultivation, was found a $\mathrm{Cd}$ level on scallops of $0.205 \mathrm{mg} / \mathrm{kg}$ without presence of $\mathrm{Pb}$ and $\mathrm{Hg}$. Close to the aquaculture areas there are industrial discharges from heterogeneous sources such as fishmeal plants, artisanal and industrial embarkation`s points, phosphate concentration plants, riverside population centers whose liquid effluents and wastewater are dumped on the coast of Sechura bay (Rebaza, 2016).

From November 2009 to April 2010, studies were conducted on Marcona marine environment. Water, sediment and organisms did not exceed the levels established by the EU, with the exception of $\mathrm{Cu}$ in mussels (the study was conducted in Mussel without visceras) which exceeded 10 ppm (IMARPE, 2010). In
2015, Cd analyzes were carried out on various foods products from a wholesale market on Lima region, including scallops and mussels (with viscera), with contents of 0.83 and $1 \mathrm{mg} / \mathrm{kg}$, respectively (Marin, 2015).

The National Fisheries Health Agency (SANIPES) has established sanitary protocols for the production areas of bivalve molluscs of Peru, the list of areas is sent to the importing countries of the European Union (Directorial Resolution No. 005-2016-SANIPES), after confirming results these are published in the web portal of Sanipes (SANIPES, 2016), which also establishes the official monitoring schedules, in the case of heavy metals in bivalve molluscs, it is each 6 months (SANIPES, 2017).

There are several scientific studies related to heavy metal monitoring in bivalve molluscs, which suggest that the most dangerous heavy metals to the marine ecosystem and human health are mercury, cadmium and lead due to their characteristics of toxicity, persistence and bioaccumulation (Besada et al., 2011; Astorga et al., 2006). In this sense, it is important to carry out on-going risk assessment, calculate the daily intake (EDI, estimated daily intake) of these metals and relate it to the PTWI (provisional tolerance weekly intake) value acceptable level of a toxic metal that can be ingested weekly as established by the World Health Organization (WHO) and FAO (FAO, 2015). The PTWI for cadmium, lead and mercury is 150, 1500 and $240 \mathrm{ug} /$ week respectively, considering a body weight of $60 \mathrm{~kg}$ (EPA, 1993; EFSA, 2011 and EFSA, 2012). In risk assessment it is also important to determine the Target Hazard Quotient (THQ), which is used to define the risk quotient that is considered acceptable. THQ values for heavy metals on shellfish oscillate from a safe level with values less than 1 , to a level of concern with values greater than 1 . The last case indicates a health risk (Bogdanovic et al., 2014).

On a suspended culture of Sechura Bay, Peru, higher contents of $\mathrm{Pb}$ and $\mathrm{Cd}$ were found in the gonads than in the abductor muscle of Peruvian scallop (Loaiza et al., 2015). $\mathrm{Pb}$ and $\mathrm{Cd}$ contents were lower than the maximum levels allowed by the EU.

In a study conducted on the southeast coast of Brazil in 2009 and 2010, the EDI of evaluated metals in two marine bivalve molluscs Perna perna (Linnaeus, 1758) and Nodipecten nodosus (Linnaeus, 1758) were compared with the reference value of PTDI (Provisional tolerable daily intake) proposed by WHO. High cadmium values in Arraial do Cabo and other studied areas were associated with upwelling occurring in that region. No EDI values exceeded the PTDI proposed by WHO (Lino et al., 2016).

The objective of the present study was to quantify the contents of $\mathrm{Pb}, \mathrm{Cd}$ and $\mathrm{Hg}$ in Peruvian scallop (Argopecten purpuratus) and mussel (Aulacomya ater), from 2009 to 2012 across the greater production areas in Peru. Afterwards, the results would be compared 
Table 1. Number of samplings performed by species and area, from 2009 to 2012.

\begin{tabular}{crrrrrr}
\hline & \multicolumn{3}{c}{ Peruvian scallop } & \multicolumn{2}{c}{ Mussel } \\
\cline { 2 - 7 } Departament & & Piura & Ancash & Ica & Ica & Arequipa \\
\hline Zona & & Sechura & Samanco & Paracas & Marcona & Atico \\
\hline \multirow{3}{*}{ Number of } & 2009 & 23 & 16 & 17 & 7 & 5 \\
samplings per year & 2010 & 3 & 9 & 3 & 3 & 3 \\
& 2011 & 8 & 19 & 13 & 3 & 3 \\
& 2012 & 10 & 3 & 3 & - & 13 \\
& Total & 44 & 47 & 36 & 13 & 24 \\
\hline
\end{tabular}

with the maximum levels established by the EU (EU, 2006) in order to carry out the health risk assessment.

\section{Materials and methods.}

Specimen sampling.

The bivalve molluscs studied were Peruvian scallop (Argopecten purpuratus) and mussel (Aulacomya ater) The number of samplings per year was made at least every 4 months. Each sample collected approximately 30-35 individuals of commercial size. In Peru, the minimum catch size allowed for scallop is $6.5 \mathrm{~cm}$ of valve height and for mussel $6.5 \mathrm{~cm}$ of valve length (PE, 2001). Sampling areas correspond to those with the highest production of these species (Figure 1). The number of samplings made by species, year and area are shown in Table 1.

After sampling, specimens were frozen with valves at $-20{ }^{\circ} \mathrm{C}$ and sent in thermal boxes with ice to the Physicochemical laboratory of the Technological Institute of Production, Callao - Peru (LABS-ITP).

Sample preparation.

Samples were partially thawed to a point which facilitated the extraction of the valves. The edible portion of scallop corresponds to the adductor muscle and gonads, eliminating its visceral content. In the case of mussel, the edible portion corresponds to the integral content of the valves. Each sample was milled with a stainless steel blade homogenizer (Resh, Grindomix GM 200) and stored in plastic bags at $-20{ }^{\circ} \mathrm{C}$ until further analysis.

Analytical methods.

The contents of $\mathrm{Pb}, \mathrm{Cd}$ and $\mathrm{Hg}$ are given on a wet weight basis (wwt) and were quantified according to methods validated and accredited by LABS-ITP, which is accredited under ISO-IEC 17025: 2005. Frozen samples before being analyzed were placed at room temperature until completely thawed, then were used for the respective analysis.

Determination of lead and cadmium.

Samples were weighed, dehydrated for 2 hours at $100{ }^{\circ} \mathrm{C}$, burned until no fumes emanated and then calcined in the muffle Barnstead Thermolyne for 14 hours at $450^{\circ} \mathrm{C}$, to ashes. The flame technique was used for quantification with an atomic absorption spectrophotometer, Perkin Elmer, Analysis 800. The readings were made at 217.0 and $228.8 \mathrm{~nm}$ for lead and cadmium respectively. The following were used for the preparation of the standard curve: Lead standard solution Merck, $1000 \mathrm{mg} / \mathrm{l}$, traceable to SRM from
NIST $\mathrm{Pb}\left(\mathrm{NO}_{3}\right)_{2}$ in $\mathrm{HNO}_{3} 0.5 \mathrm{~mol} / \mathrm{l}$ and Cadmium standard solution Merck, $1000 \mathrm{mg} / \mathrm{l}$, traceable to SRM from NIST Cd $\left(\mathrm{NO}_{3}\right)_{2}$ in $\mathrm{HNO}_{3} 0.5 \mathrm{~mol} / \mathrm{l}$.

Determination of mercury.

Acid digestion was applied to the samples $(\mathrm{HCl}$, $\mathrm{HNO}_{3}$ y $\mathrm{H}_{2} \mathrm{SO}_{4}$ ) in a water bath at 60 to $70{ }^{\circ} \mathrm{C}$ of temperature for about $120 \mathrm{~min}$. The cold vapor technique was applied by atomic fluorescence spectrophotometry on a Quick Trace M-8000 mercury analyzer. The following were used for the preparation of the standard curve: Mercury standard solution Merck, $1000 \mathrm{mg} / \mathrm{l}$, traceable to SRM from NIST $\mathrm{Hg}\left(\mathrm{NO}_{3}\right)_{2}$ in $\mathrm{HNO}_{3} 2 \mathrm{~mol} / \mathrm{l}$.

Detection limits (LD) for $\mathrm{Pb}, \mathrm{Cd}$ and $\mathrm{Hg}$ were 0.03 ; 0.003 and $0.01 \mathrm{ug} / \mathrm{g}$ respectively and the quantification limits (LQ) were $0.07 ; 0.01$ and $0.02 \mathrm{ug} / \mathrm{g}$ respectively. Quality control.

Quality controls for analytical results were performed. The acids used were ultrapure grade. Each sample was analyzed in duplicate. The coefficient of determination of the calibration curves was greater than 0.995 and for each run a recovery test was performed with a range of 80 to $110 \%$ (Taverniers et al., 2004). The laboratory is constantly involved in international aptitude tests and has reference materials for these elements. The analysis of a certified reference material (Mussel Tissue 2976, National Institute of Standards and Technology) was performed in the same way as the samples for each analytical method and the results on dry basis (bs) of $1.15 \pm 0.12 \mathrm{ug} / \mathrm{g} \mathrm{Pb}, 0.85 \pm 0.10 \mathrm{ug} / \mathrm{g}$ $\mathrm{Cd}$ and $60.2 \pm 2.1 \mathrm{ug} / \mathrm{kg} \mathrm{Hg}$, were in the acceptance range of their certificate $(1.19 \pm 0.18 \mathrm{ug} / \mathrm{g} \mathrm{Pb}, 0.82 \pm$ $0.16 \mathrm{ug} / \mathrm{g} \mathrm{Cd}$ and $61.0 \pm 3.6 \mathrm{ug} / \mathrm{kg} \mathrm{Hg}$ ).

Data treatment for risk assessment.

Contents of $\mathrm{Pb}, \mathrm{Cd}$ and $\mathrm{Hg}$ were directly compared with the maximum levels established by the EU of 1.5; 1.0 and $0.5 \mathrm{ug} / \mathrm{g}$ respectively (EU, 2006).

Estimated daily intake (EDI), was calculated with the average contents of heavy metals obtained from

Table 2. Shellfish per capita consumption in Perú.

\begin{tabular}{ccc}
\hline Year & $\begin{array}{c}\text { Shellfish consumption } \\
(\mathrm{kg} / \text { year })\end{array}$ & $\begin{array}{c}\text { IR } \\
(\mathrm{g} / \text { day })\end{array}$ \\
\hline 2009 & 1.95 & 5.34 \\
\hline 2010 & 4.31 & 11.81 \\
\hline 2011 & 5.21 & 14.27 \\
\hline 2012 & 5.14 & 14.08 \\
\hline
\end{tabular}

Source: FAOSTAT, 2015. 
scallop and mussel (ug/kg/day), for each area and year using the following equation (1).

$$
\mathrm{EDI}=C_{m} \mathrm{x} \frac{\mathrm{IR}}{B_{w a}} \ldots
$$

Where $\mathrm{C}_{\mathrm{m}}$ is the metal concentration in bivalve (ug/g); IR, the daily ingestion rate per person (g/day), was used specifically for each year of study according to Table 2 and Bwa represents the average body weight of a Peruvian adult $(60 \mathrm{~kg})$.

To determine THQ for cadmium and mercury, equation 2 was used,

$$
T H Q=\frac{(E F \times E D \times I R \times C m) \times 10^{-3}}{R f d \times B w a x A E T} \ldots . .(2)
$$

EF is the exposure frequency ( $350 \mathrm{~d} /$ year); $\mathrm{ED}$, the total exposure duration (30 years) (Loaiza et al., 2015); $\mathrm{IR}$, daily ingestion rate (g/day); $\mathrm{Cm}$, metal concentration in the edible portion of bivalve (ug/g);

$\mathrm{Rfd}$, reference dose, oral (ug/g/day), (according to EPA, 2000); Bwa: average adult body weight (60 kg); AET: average time noncarcinogens (ED x $365 \mathrm{~d} /$ year) and $10^{-3}$ is the conversion factor.

The Agency's Rfd Work Group discussed inorganic lead and lead compounds at two meetings (07/08/1985 and 07/22/1985) and suggested that it was inappropriate to express Rfd for inorganic lead (EFSA, 2013; IRIS, 2004). To determine THQ for Pb equation 3 was used (Liu et al., 2009),

$T H Q=\frac{C m}{M R l} \ldots \ldots . .$.

Where $\mathrm{Cm}$ is the metal concentration in bivalve ( $\mathrm{ug} / \mathrm{g}$ ) and MRl is the Maximum Reference level, the limit set by the Official Journal of the European Union, Commission Regulation $N^{\circ} 1881 / 2006$, (EU, 2006). Statistical analysis.

The SPSS v20 software was used to compare $\mathrm{Pb}, \mathrm{Cd}$ and $\mathrm{Hg}$ concentrations from the edible portion of Peruvian scallop and mussel in relation to their extraction areas and each year of study. Normality tests and homogeneity of variances were performed, applying Shapiro-wilk and Levene's test respectively. ANOVA and Dunnet test were used to establish differences ( $\mathrm{p}<0.05)$ from these concentrations obtained during the study years for each area.

\section{Results and discussion. \\ Lead.}

The average concentrations of lead in scallops and mussels in the study areas were lower than the maximum level allowed.

The average concentrations of lead in scallop from Sechura did not present significant differences from 2009 to 2012 (Figure 2 a,b), the same behavior was observed with scallops from Samanco and Paracas (Table 3). Regarding the contents of $\mathrm{Pb}$ in mussel, the concentrations from Atico in 2009 and 2010 were higher than Marcona. However, every year there is a decrease in lead concentrations in Atico.

Similar values were reported in Semimytilus algosus (Gould, 1850) from White Island in Peru, with an average content express on dry weight (dw) of 0.7 ug $\mathrm{Pb} / \mathrm{g}$ (Jacinto \& Aguilar, 2007). Aulocomya ater with 0.31 and $0.36 \mathrm{ug} \mathrm{Pb} / \mathrm{g}(\mathrm{dw})$ and Mytilus edulis with 0.21 and $0.42 \mathrm{ug} \mathrm{Pb} / \mathrm{g}(\mathrm{dw})$ at Punta Maqueda and Arroyo La Mata respectively (Perez et al., 2005). At Chetumal Quintana Roo bahia, Mexico, mussel (Mytilopsis sallei Récluz, 1849) were evaluated, finding $\mathrm{Pb}$ in the range of 0.31 to $3.23 \mathrm{ug} / \mathrm{g}$ (dw) (Diaz et al., 2006); in the same way Yap et al., (2016) found on Perna viridis at peninsular coast of Malaysia, 0.27 to $10.4 \mathrm{ug} \mathrm{Pb} / \mathrm{g}$ (wwt).

Cadmium.

The average concentrations of $\mathrm{Cd}$ in scallop from 2009 to 2012, were lower than the maximum level allowed and did not show significant differences on each study areas (Table 3).

The average concentration of $\mathrm{Cd}$ in mussel from Marcona did not show significant differences from 2009 to 2011 (Table 3), however mussel from Atico presented fluctuating values during the study period. Mussels from Atico presented higher values than Marcona, and in both cases exceeded the maximum level established by the EU of $1 \mathrm{ug} / \mathrm{g}$. In 2009, mussels

\begin{tabular}{|c|c|c|c|c|c|c|c|c|c|c|c|c|}
\hline \multirow[b]{2}{*}{ Species } & \multirow[b]{2}{*}{ Area } & \multicolumn{4}{|c|}{$\mathrm{Pb}$} & \multicolumn{4}{|c|}{$\mathrm{Cd}$} & \multicolumn{3}{|c|}{$\mathrm{Hg}$} \\
\hline & & 2009 & 2010 & 2011 & 2012 & 2009 & 2010 & 2011 & 2012 & 2010 & 2011 & 2012 \\
\hline \multirow{6}{*}{$\begin{array}{l}\text { Peruvian } \\
\text { scallop } \\
\text { (Argopecten } \\
\text { purpuratus) }\end{array}$} & SECHUR A & $0.082^{\mathrm{a}}$ & $0.093^{\mathrm{a}}$ & $0.079^{\mathrm{a}}$ & $0.075^{\mathrm{a}}$ & $0.180^{\mathrm{a}}$ & $0.217^{\mathrm{ab}}$ & $0.205^{\mathrm{ab}}$ & $0.240^{\mathrm{b}}$ & $0.023^{\mathrm{a}}$ & $0.016^{\mathrm{a}}$ & $0.015^{\mathrm{a}}$ \\
\hline & ЗЕСПUКА & \pm 0.032 & \pm 0.032 & \pm 0.021 & \pm 0.014 & \pm 0.053 & \pm 0.029 & \pm 0.054 & \pm 0.045 & \pm 0.006 & \pm 0.007 & \pm 0.005 \\
\hline & SAM & $0.098^{\mathrm{a}}$ & $0.102^{a}$ & $0.091^{\mathrm{a}}$ & $0.077^{\mathrm{a}}$ & $0.209^{\mathrm{a}}$ & $0.242^{\mathrm{a}}$ & $0.256^{\mathrm{a}}$ & $0.223^{\mathrm{a}}$ & $0.029^{\mathrm{a}}$ & $0.017^{\mathrm{b}}$ & $0.017^{\mathrm{b}}$ \\
\hline & SAIVANCU & \pm 0.048 & \pm 0.022 & \pm 0.029 & \pm 0.029 & \pm 0.068 & \pm 0.080 & \pm 0.050 & \pm 0.085 & \pm 0.011 & \pm 0.008 & \pm 0.006 \\
\hline & & $0.089^{\mathrm{a}}$ & $0.100^{\mathrm{a}}$ & $0.079^{\mathrm{a}}$ & $0.093^{\mathrm{a}}$ & $0.243^{\mathrm{a}}$ & $0.300^{\mathrm{a}}$ & $0.253^{\mathrm{a}}$ & $0.343^{\mathrm{a}}$ & $0.029^{\mathrm{a}}$ & $0.022^{a}$ & $0.020^{\mathrm{a}}$ \\
\hline & PARACAS & \pm 0.047 & \pm 0.044 & \pm 0.030 & \pm 0.029 & \pm 0.082 & \pm 0.053 & \pm 0.050 & \pm 0.065 & \pm 0.002 & \pm 0.008 & \pm 0.010 \\
\hline \multirow{3}{*}{$\begin{array}{l}\text { Mussel } \\
\text { (Aulacomya } \\
\text { ater) }\end{array}$} & MARCONA & $0.120^{\mathrm{a}}$ & $0.123^{\mathrm{a}}$ & $0.127^{a}$ & $\mathrm{Nd}$ & $1.622^{\mathrm{a}}$ & $1.360^{\mathrm{a}}$ & $1.227^{\mathrm{a}}$ & nd & $0.033^{\mathrm{a}}$ & $0.027^{\mathrm{a}}$ & nd \\
\hline & & $\begin{array}{r} \pm 0.030 \\
0234^{\mathrm{a}}\end{array}$ & \pm 0.006 & \pm 0.012 & 0094 & & \pm 0.321 & \pm 0.253 & 134 & \pm 0.015 & \pm 0.006 & \\
\hline & ATICO & $\begin{array}{c}0.234^{4} \\
\pm 0.078\end{array}$ & $\begin{array}{r}0.150 \\
\pm 0.053\end{array}$ & $\begin{array}{r}0.153^{\circ} \\
\pm 0.023\end{array}$ & $\begin{array}{r}0.094 \\
\pm 0.025\end{array}$ & $\begin{array}{r}2.569^{4} \\
\pm 1.284\end{array}$ & $\begin{array}{l}1.893 \\
\pm 0.691\end{array}$ & $\begin{array}{l}2.4 / 3 \\
\pm 1.085\end{array}$ & $\begin{array}{r}1.340^{\circ} \\
\pm 0.344\end{array}$ & $\begin{array}{l}0.023^{\circ} \\
\pm 0.006\end{array}$ & $\begin{array}{r}0.033^{\circ} \\
\pm 0.015\end{array}$ & $\begin{array}{r}0.022^{\circ} \\
\pm 0.004\end{array}$ \\
\hline
\end{tabular}

Table 3. Heavy metal concentration, mean \pm standard deviation (ug. $\mathrm{g}^{-1}$ wwt).

Equal letters in rows of each element, have no significant differences ( $>>0.05)$.

Different letters in rows of each element, have significant differences $(\mathrm{p}<0.05)$.

nd: no sampling. 
from Atico reaches up to 4 times the maximum reference level in $\mathrm{Cd}$. (Figure $2 \mathrm{c}$ and $\mathrm{d}$ ).

Yap et al. (2016) evaluate mussel Perna viridis (Linnaeus, 1758) in the Malaysian Peninsula from 2002 to 2009 finding values of 0.06 to $0.53 \mathrm{ug} \mathrm{Cd} / \mathrm{g}$ (wwt). Jacinto \& Aguilar (2007) report average Cd concentration of $1.3 \mathrm{ug} / \mathrm{g}(\mathrm{dw})$ in mussel (Semimytilus algosus) from White Island of Peru, being lower values than found at Atico and Marcona of this study, possibly because at White Island there were no anthropogenic sources nearby.

High concentrations of cadmium in mussel of the present study, may be due to the oceanographic phenomenon of upwelling, present in the Peruvian sea, which favors the dispersion of heavy metals. Another explanation for the presence of heavy metals at the Peruvian sea is the industrialization and growth population that have led to an increase in metals through municipal and industrial effluents, petroleum activities and drainage from mining activities, causing adverse effects on ecosystems.

Atico, carry out the processing of the extracted mineral in auriferous deposits near to the zone, it is probable that the mining activity contributes with the increase of $\mathrm{Cd}$ in this area.

Mercury.

As in the case of lead, all the concentrations of mercury in scallop and mussel were lower than the maximum level allowed by EU (2006). Mercury concentrations in mussel did not present significant differences in relation to the sampling area and years evaluated (Table 3).
Several research studies mention than mercury concentrations in bivalves present less than the maximum amount established by the EU (Besada et al., 2011; Gutiérrez et al., 2006; Olmedo et al., 2013). However, Gonzales-Fernández et al. (2015), found higher levels of $\mathrm{Hg}$ from 0.461 to $0.852 \mathrm{ug} / \mathrm{g}$ (dw) in mussel (Mytillus gallopronuncialis) in Spain.

Risk evaluation.

The highest values of weekly lead intakes by consumption of scallop were $9.17 \mathrm{ug} /$ week (Paracas in 2012; and $15.29 \mathrm{ug} /$ week for mussel was (Atico 2011); equivalent to 0.6 and $1 \%$ of PTWI respectively.

In the case of mercury, the highest values of weekly intake of scallop were $2.40 \mathrm{ug} /$ week (Samanco and Paracas in 2010) and for mussel, $3.30 \mathrm{ug} /$ week (Atico in 2011), corresponding to 1 and $2.1 \%$ of PTWI respectively.

The content of lead and mercury in scallop and mussel were not a health risk. Regarding cadmium, the highest annual mean of weekly intake for scallop consumption were $33.81 \mathrm{ug} /$ week (Paracas in 2012) and for mussel was $247 \mathrm{ug} /$ week (Atico in 2011), corresponding to 22.5 and $164.7 \%$ of PTWI respectively. This last value was high, and considered a health risk (Table 4). Therefore, a maximum weekly consumption rate of mussel was determined for Marcona: 21, 58 and $69 \mathrm{~g}$ for children $(18 \mathrm{~kg})$, adults of 50 and $60 \mathrm{~kg}$ respectively. In the case of mussel from Atico, consumption should not exceed 5, 13 and $15 \mathrm{~g}$ for children $(18 \mathrm{~kg})$, adults of 50 and $60 \mathrm{~kg}$ respectively.

Table 4. EDI, THQ, Weekly intake y \% PTWI.

\begin{tabular}{|c|c|c|c|c|c|c|c|c|c|c|c|c|c|c|}
\hline & \multirow[b]{2}{*}{ Area } & \multirow[b]{2}{*}{ Year } & \multicolumn{4}{|c|}{ LEAD } & \multicolumn{4}{|c|}{ CADMIUM } & \multicolumn{4}{|c|}{ MERCURY } \\
\hline & & & $\begin{array}{l}\text { EDI } \\
\text { (ug/kg/ } \\
\text { dia) }\end{array}$ & THQ & $\begin{array}{c}\text { Weekly } \\
\text { intake } \\
\text { (ug/week) } \\
*\end{array}$ & $\begin{array}{c}\% \\
\text { PTWI }\end{array}$ & $\begin{array}{l}\text { EDI } \\
\text { (ug/kg/ } \\
\text { dia) }\end{array}$ & THQ & $\begin{array}{c}\text { Weekly } \\
\text { intake } \\
\text { (ug/week) } \\
*\end{array}$ & $\begin{array}{c}\% \\
\text { PTWI }\end{array}$ & $\begin{array}{l}\text { EDI } \\
\text { (ug/kg/ } \\
\text { dia) }\end{array}$ & THQ & $\begin{array}{c}\text { Weekly } \\
\text { intake } \\
\text { (ug/week) } \\
*\end{array}$ & $\begin{array}{c}\% \\
\text { PTWI }\end{array}$ \\
\hline \multirow{12}{*}{ 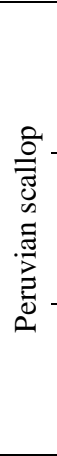 } & \multirow{4}{*}{ Sechura } & 2009 & 0.007 & 0.055 & 3.07 & 0.2 & 0.016 & 0.070 & 6.73 & 4.5 & & & & \\
\hline & & 2010 & 0.018 & 0.062 & 7.69 & 0.5 & 0.043 & 0.085 & 17.94 & 12.0 & 0.005 & 0.009 & 1.90 & 0.8 \\
\hline & & 2011 & 0.019 & 0.053 & 7.89 & 0.5 & 0.049 & 0.080 & 20.48 & 13.7 & 0.004 & 0.006 & 1.60 & 0.7 \\
\hline & & 2012 & 0.018 & 0.050 & 7.39 & 0.5 & 0.056 & 0.094 & 23.66 & 15.8 & 0.004 & 0.006 & 1.48 & 0.6 \\
\hline & \multirow{4}{*}{ Samanco } & 2009 & 0.009 & 0.065 & 3.66 & 0.2 & 0.019 & 0.082 & 7.82 & 5.2 & & & & \\
\hline & & 2010 & 0.020 & 0.068 & 8.43 & 0.6 & 0.048 & 0.094 & 20.00 & 13.3 & 0.006 & 0.011 & 2.40 & 1.0 \\
\hline & & 2011 & 0.022 & 0.061 & 9.09 & 0.6 & 0.061 & 0.100 & 25.58 & 17.1 & 0.004 & 0.007 & 1.70 & 0.7 \\
\hline & & 2012 & 0.018 & 0.051 & 7.59 & 0.5 & 0.052 & 0.087 & 21.98 & 14.7 & 0.004 & 0.007 & 1.68 & 0.7 \\
\hline & \multirow{4}{*}{ Paracas } & 2009 & 0.008 & 0.059 & 3.33 & 0.2 & 0.022 & 0.095 & 9.09 & 6.1 & & & & \\
\hline & & 2010 & 0.020 & 0.067 & 8.27 & 0.6 & 0.059 & 0.117 & 24.80 & 16.5 & 0.006 & 0.011 & 2.40 & 1.0 \\
\hline & & 2011 & 0.019 & 0.053 & 7.89 & 0.5 & 0.060 & 0.099 & 25.29 & 16.9 & 0.005 & 0.009 & 2.20 & 0.9 \\
\hline & & 2012 & 0.022 & 0.062 & 9.17 & 0.6 & 0.081 & 0.134 & 33.81 & 22.5 & 0.005 & 0.008 & 1.97 & 0.8 \\
\hline \multirow{7}{*}{ 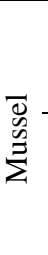 } & \multirow{3}{*}{ Marcona } & 2009 & 0.011 & 0.080 & 4.49 & 0.3 & 0.144 & 0.633 & 60.66 & 40.4 & & & & \\
\hline & & 2010 & 0.024 & 0.082 & 10.17 & 0.7 & 0.268 & 0.530 & 112.41 & 74.9 & 0.006 & 0.013 & 2.73 & 1.1 \\
\hline & & 2011 & 0.030 & 0.085 & 12.69 & 0.8 & 0.292 & 0.479 & 122.60 & 81.7 & 0.006 & 0.011 & 2.70 & 1.1 \\
\hline & \multirow{4}{*}{ Atico } & 2009 & 0.021 & 0.156 & 8.75 & 0.6 & 0.229 & 1.002 & 96.07 & 64.0 & & & & \\
\hline & & 2010 & 0.030 & 0.100 & 12.40 & 0.8 & 0.373 & 0.738 & 156.47 & 104.3 & 0.005 & 0.009 & 1.90 & 0.8 \\
\hline & & 2011 & 0.036 & 0.102 & 15.29 & 1.0 & 0.588 & 0.964 & 247.10 & 164.7 & 0.008 & 0.013 & 3.30 & 1.4 \\
\hline & & 2012 & 0.022 & 0.063 & 9.27 & 0.6 & 0.316 & 0.525 & 132.68 & 88.5 & 0.005 & 0.009 & 2.17 & 0.9 \\
\hline
\end{tabular}

Note: PTWI using Rfd (ug/kg/day) $=0.5$ for Cd.

(*) The weekly intake was calculated with the EDI, it was considered a body weight of $60 \mathrm{~kg}$. 
There are reports of risk assessment of heavy metals intake by bivalves consumption. Perez et al. (2005), evaluated Aulacomya ater and Mytilus edulis platensis from Punta Maqueda and concluded that a consumption of $368 \mathrm{~g} /$ week (approximately 76 units) would reach the weekly intake limit set by JEFCA for $\mathrm{Cd}$. In addition, Sobrino-Figueroa et al. (2007) analyzed clams (Argopecten ventricosus) collected from Pichilingue Port $\left(24^{\circ} 15.364^{\prime} \mathrm{N}, 110^{\circ} 19.137^{\prime} \mathrm{W}\right)$ and

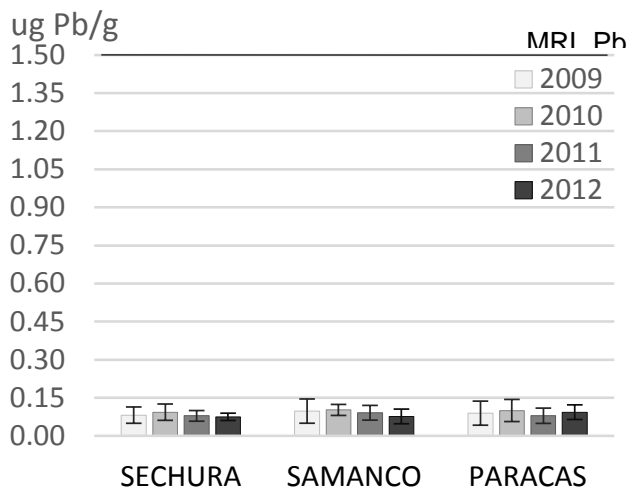

(a) Peruvian scallop

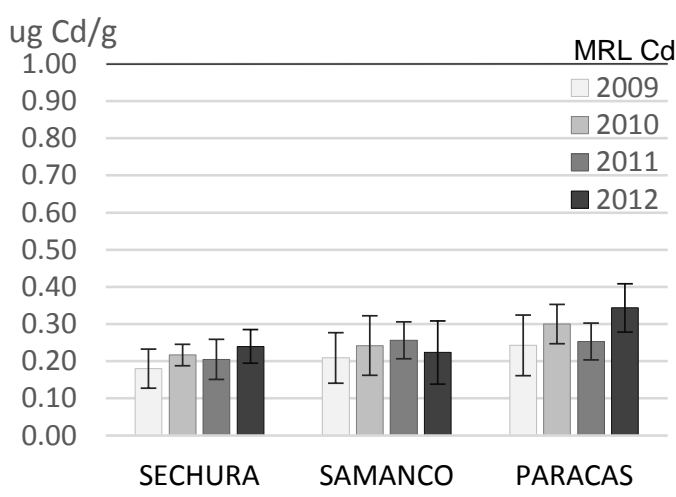

(c) Peruvian scallop

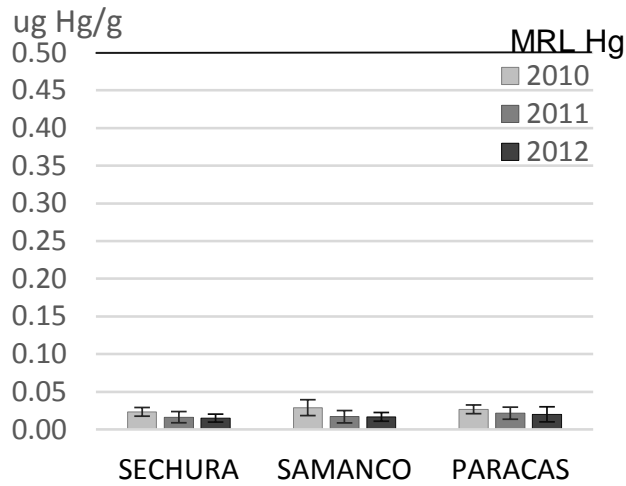

(e) Peruvian scallop finaly recommended to consume $6.99 ; 97.09$ and $135.92 \mathrm{~g}$ for children $(18 \mathrm{~kg})$, adults of $50 \mathrm{~kg}$ and $60 \mathrm{~kg}$ respectively, in order to not exceed the reference dose for $\mathrm{Cd}$. Higher rations of consumption could imply a health risk.

Olmedo et al. (2013) carried out a risk assessment for consumption of fish and shellfish in Southern Spain. The maximum weekly consumption rate of $\mathrm{Pb}, \mathrm{Cd}$ and $\mathrm{Hg}$ for a person weighing $60 \mathrm{~kg}$ was $75.95 \mathrm{ug} /$ week $(5 \%$

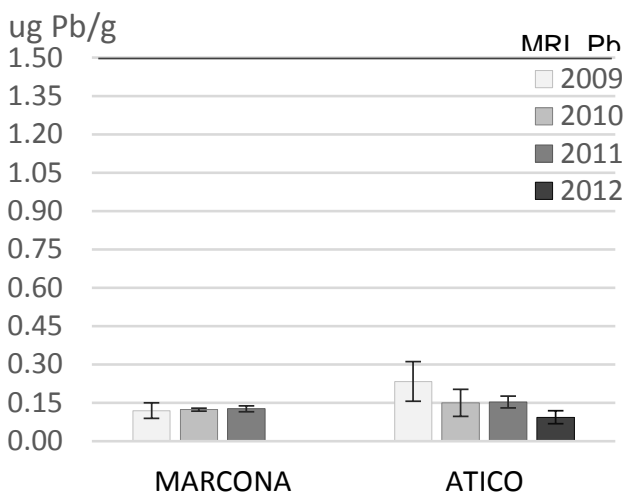

(b) Mussel

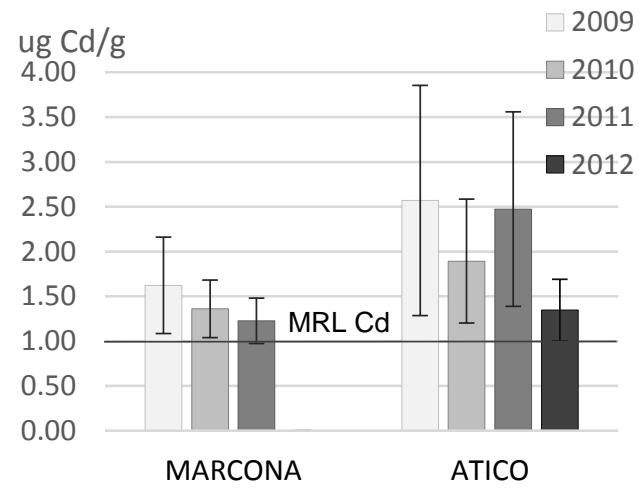

(d) Mussel

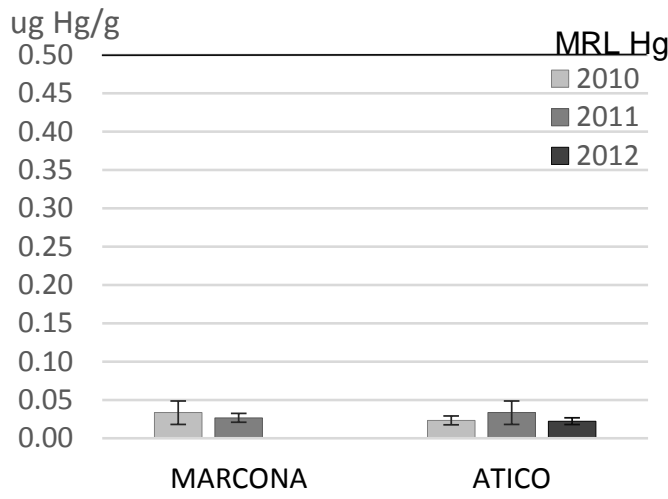

(f) Mussel

MRL: maximum level allowed by EU.

Figure 2. Concentration of lead, cadmium and mercury (wwt) in Peruvian scallop (a, c, e) and mussel (b, $\mathrm{d}, \mathrm{f})$ by sampling area. 
of PTWI), $17.57 \mathrm{ug} /$ week (12\% of PTWI) and 63.63 ug/week $(81.5 \%$ of PTWI) respectively. Mercury content has the highest health risk.

The EDI annual averages for $\mathrm{Pb}$ in scallop calculated in the present study (Table 4) were below the values determined by Loaiza et al. (2015) for the same species $(0.043-0.064 \mathrm{ug} / \mathrm{kg} /$ day $)$, with none of them posing a health risk.

Yap et al. (2016) determined cadmium weekly intakes of 15.9 and $31.8 \%$ of PTWI when consuming $0.125 \mathrm{~kg}$ and $0.250 \mathrm{~kg}$ of mussel (Perna viridis) respectively, indicating no health risk.

\section{Conclusions.}

1. Cadmium is the toxic element most concentrated in mussels and scallops in the studied areas. The maximum value of $\mathrm{Cd}$ reached in scallops was 0.4 $\mathrm{mg} / \mathrm{kg}$, being lower than the maximum level allowed by the EU (1 mg/kg), meanwhile in the mussel it was much higher, reached in 2009 values of 4 times the maximum level allowed.

2. The values of $\mathrm{Pb}$ and $\mathrm{Hg}$ for scallops and mussels, in all areas and years of study were lower than the maximum level allowed by the $\mathrm{EU}$, bein for $\mathrm{Pb}$ and $\mathrm{Hg} 1.5$ and $0.5 \mathrm{mg} / \mathrm{kg}$ respectively.

3 . The highest concentrations of cadmium in scallop represented values of $15.8 \%, 17.1 \%$ and $22.5 \%$ of PTWI in Sechura, Samanco and Paracas respectively. Mussel reached $81.7 \%$ and $164.7 \%$ of PTWI for Marcona and Atico respectively, representing a health risk.

4. THQ value for $\mathrm{Cd}$ in mussel was higher than 1 in Marcona and Attico, representing a health risk.

5. It is recommended, a maximum weekly consumption of mussel from Marcona of 21; 58 and $69 \mathrm{~g}$ for children $(18 \mathrm{~kg})$, adults of $50 \mathrm{~kg}$ and $60 \mathrm{~kg}$ respectively. The consumption of mussel from Atico should not exceed 5; 13 and $15 \mathrm{~g}$ for children $(18 \mathrm{~kg})$, adults of $50 \mathrm{~kg}$ and $60 \mathrm{~kg}$ respectively.

\section{Literatura citada.}

Alamo V. \& Valdivieso V. 1997. Lista sistemática de moluscos marinos del Perú. Instituto del Mar del Perú. IMARPE. Segunda edición.

Astorga M., Rodríguez E. \& Díaz C. 2006. Comparison of mineral and trace element concentrations in two molluscs from the Strait of Magellan (Chile). Journal of food composition and analysis 20 (2007): 273-279.

Besada V., Andrade J., Shultze F \& Gonzales J. 2011. Monitoring of heavy metals in wild mussels (Mytilus galloprovincialis) from the Spanish North-Atlantic coast. Continental Shelf Research 31 (2011) 457-465.

Bogdanovic T., Ujevic I., Sedak M., Listes E., Simat V., Petricevic S. \& Poljak V., 2014. As, Cd, $\mathrm{Hg}$ and $\mathrm{Pb}$ in four adible shellfish species from breeding and harvesting areas along the eastern Adriatic Coast, Croatia. Food Chem. 146. 197-203.

Diaz C., Carrion J. \& Gonzalez J. 2006. Estudio de la contaminación por $\mathrm{Hg}, \mathrm{Pb}, \mathrm{Cd}$ y $\mathrm{Zn}$ en la bahía de
Chetumal, Quintana Roo, México. Rev. Soc. Quím. Perú [online]. Vol.72, n.1, pp. 19-31.

EFSA (European Food Safety Authority). 2011. Scientific Opinion of the panel on Contaminants in the Food Chain on a request from the European Commission on cadmium in food. EFSA J. 9(2):1975.

EFSA (European Food Safety Authority). 2012. Scientific Opinion of the risk for public health related to the presence of mercury and methylmercury in food. EFSA panel on Contaminants in the Food Chain. EFSA Journal 10 (12):2985.

EFSA (European Food Safety Authority). 2013. Scientific Opinion of the panel on Contaminants in the Food Chain on a request from the European Commission on lead in food.EFSA J. 8 (4) 1570.

EPA (U.S. Enviromental Protection Agency). 1993. Enviromental Protection Agency Region III. Selecting EPA Exposure Routes and Contaminants of concern by Risk- Based Screening. Hazardous Waste Management Division Office of Superfund Programs January.

EPA (U.S. Enviromental Protection Agency). 2000. Guidance for assessing chemical contaminant data for use in fish advisories. Volume 2: Risk assessment and fish consumption limits. Third Edition. EPA 823-B-00-008.

EU. 2006. Commission regulation (EC) No 1881/2006. Setting maximum levels for certain contaminants in foodstuff. L 364/ 5-24. Official Journal of the European Union.

FAO. 2015. (Food Administration Organization). FAOSTAT, Food Balance Sheets.

Gamarra A. \& Cornejo O. 2002. Study of the mussel Aulacomya ater, molina 1782 (Bivalvia:Mytilidae), near Santa Rosa Island, Independence Bay, Perú the during the El Niño Phenomenon 1997-1998. Investig. Mar, v.30 N.1 Supl. Symp Valparaiso.

Gonzales-Fernández C., Albentosa M., Campillo J., Viñas L., Fumega J., Franco A., Besada V., Gonzales Quijano A. \& Bellas J. 2015. Influence of Mussel biological variability on pollution biomarkers. Environmental Research 137:14-31.

Gutiérrez A., Lozano G., González T., Ignacio Reguera J. \& Hardisson A. 2006. Mercury content in tinned molluscs (mussel, cockle, variegated scallop, and razor shell) normally consumed in Spain, 2005. J Food Prot. 2006 Sep;69(9):2237-40.

IMARPE (Instituto del Mar del Perú). 2009. Informe final estudio de linea base en el ambito marino de bahia de samanco 13 - 24 diciembre 2008. Chimbote, Febrero del 2009.

IMARPE (Instituto del Mar del Perú). 2010. Caracterización Bio oceanográfica del área marino costera entre Punta San Juan y playa Yanyarina. Convenio específico de Cooperación institucional entre la Municipalidad Distrital de Marcona y el Instituto del Mar del Perú-Convenio $\mathrm{N}^{\circ}$ 016-2008-IMARPE.Noviembre 2009- Abril 2010. 55pp

IMARPE (Instituto del Mar del Perú). 2013. Informe de Investigacion Cientifica y Tecnológica. Diagnóstico de las poblaciones de los recursos pesqueros para el ordenamiento como base para su sostenibilidad y seguridad alimentaria. Evaluación del POI-PTI al III Trimestre del 2013. 184 pp.

IRIS (Integrates Risk Information System). 2004.. Chemical Assessment Summary. U.S. Environmental Protection 
Agency National Center for Environmental Assessment. Lead and compounds (inorganic).

Jacinto M. \& Aguilar S. 2007. Concentraciones traza de metales en especies marinas de la Bahia de Huarmey, Ancash, Perú, Rev. Peru. Biol. 14 (2): 307-311.

Lino A.S., Galvo P.M.A., Longo R.T.L., Azevedo-Silva C.E., \& Dorneles P.R. 2016. Metal bioaccumulation in consumed marine bivalves in Southeast Brazilian coast. Journal of Trace Elements in Medicine and Biology 34, $50-55$.

Liu F., Ge J., Hu X., Fei T., Li Y., Jiang Y., Xu Z., Ding S., Giesy J.P. \& Pan J. 2009. Risk to humans of consuming metals in anchovy (Coilia sp.) from the Yangtze River Delta. Environ Geochem Health (2009) 31:727-740.

Loaiza I., Hurtado D., Miglio M., Orrego H. \& Mendo J. 2015. Tissue-specific $\mathrm{Cd}$ and $\mathrm{Pb}$ accumulation in Peruvian scallop (Argopecten purpuratus) transplanted to a suspended and bottom culture at Sechura Bay, Peru. J. Marine Pollution Bulletin 91: 429-440.

Marin G. 2015. Contaminación de alimentos marinos por cadmio en Lima, Apunt. cienc. soc.; 05(02) 2015. DOI: http://dx.doi.org/10.18259/acs.2015038

Olmedo P., Pla A., Hernandez A., Barbier F., Ayouni L. \& Gil F. 2013. Determination of toxic elemnts (mercury, cadmium, lead, tin and arsenic) in fish and shelfish samples. Risk assessment for the consumers. Environment International 59, 63-72.

PE (PERÚ, Ministerio de la Producción). 2001. Resolución Ministerial $N^{\circ}$ 209-2001-PE (promulgada el 26 de junio de 2001). Aprueban relación de tallas mínimas de captura y tolerancia máxima de ejemplares juveniles de principales peces marinos e invertebrados. En Diario Oficial El Peruano, Lima 27 de junio 2001. Perú.

PE (PERÚ, Ministerio de la Producción). 2016. Anuario Estadístico Pesquero y acuícola 2015. 33pp.
Perez A., Fajardo M., Strobl A., Perez L., Piñeiro A. \& Lopez M. 2005. Contenido de plomo, cromo, cadmio en moluscos comestibles del Golfo San Jorge (Argentina). Acta Toxicol. Argent. 13 (1): 20-25.

Rebaza R., 2016. Evaluación de la contaminación por bioacumulación de $\mathrm{Cd}, \mathrm{Pb}$ y $\mathrm{Hg}$ en moluscos bivalvos en la zona de amortiguamiento de la bahía de Sechura durante Agosto-Diciembre de 2015.Trabajo de investigación de Ingeniero químico. Universidad de Trujillo.

SANIPES (Organismo Nacional de Sanidad Pesquera). 2016. Procedimiento: Control oficial de zonas y Areas de producción Clasificadas de Moluscos Bivalvos. Julio 2016.

$16 \mathrm{pp}$. http://www.sanipes.gob.pe/procedimientos/P02-SDSASANIPES-REV1-2016-JUL.pdf

SANIPES (Organismo Nacional de Sanidad Pesquera). 2017. Resolucion de dirección ejecutiva $\quad \mathrm{N}^{\circ} 073-2017$ SANIPES-DE.

http://www.sanipes.gob.pe/procedimientos/RDE_0732017_SANIPES_P02-SDSA-SANIPES.pdf

Sobrino-Figueroa A., Caceres C. \& Rosas-Cedillo R., 2007. Evaluación del riesgo por consumir moluscos contaminados con cadmio, cromo y plomo. Hidrobiológica $17 \mathrm{~N}^{\circ} 1$. Suplemento.

Taverniers I., De Loose M. \& Van Bockstaele E. 2004. Trends in Analytical Chemistry, Vol. 23, $\mathrm{N}^{\circ}$ 8. Trends in Quality in the Analytical Laboratory. Pag 535 a 552.

Yap C.K., Cheng W.H., Karami A. \& Ismail A. 2016. Health risk assessments of heavy metal exposure via consumption of marine mussel collected from anthropogenic sites. Science of the Total Environment $553,285-296$.

\footnotetext{
${ }^{1}$ Direction of Research. Technological Institute of Production. Carretera a Ventanilla km 5.2 Callao. Perú. maritza_barriga@hotmail.com.
} 